\title{
Ontogenetic structure of Ziziphora interrupta (Lamiaceae) coenopopulations in Tajikistan
}

\author{
Vera Cheryomushkina ${ }^{1 *}$, Kobil Bobokalonov ${ }^{2},{\text { Mariyo } \text { Boboev }^{3} \text {, and Natalia Kurochkina }}^{1}$ \\ ${ }^{1}$ Central Siberian Botanical Garden SB RAS, 630090 Novosibirsk, Russia \\ ${ }^{2}$ Institute of Botany, Physiology and Plant Genetics, AS RT, Dushanbe, Tajikistan \\ ${ }^{3}$ Khatlon Science centre AS RT 735360 Kulyab, Tajikistan
}

\begin{abstract}
The structure of five Ziziphora interrupta coenopopulations in Tajikistan was described in the article. It was found that most coenopopulations are stable, have a centered ontogenetic spectrum with a maximum on mature generative individuals. This is due to the slow rates rates of plant development in the middle and fast at the beginning and end of ontogenesis. The deviation from the typical centered spectrum is associated with the irregularity of seed renewal and the polyvariant ontogeny of individuals growing on mobile substrates and steepness of slopes. The right-sided spectrum is formed as a result of anthropogenic impact (collection of medicinal raw materials), what leads to a gradual aging of the coenopopulation and its loss from the community.
\end{abstract}

The regions of Central Asia are active floristic zones of speciation, where a large number of rare and endemic plants are concentrated [1]. In the mountain ecosystems of Tajikistan, there are concentrations of the endemic species of the family Lamiaceae L. representatives [2], which are of both strategic importance for economic and practical purposes, and for the creation of various theoretical concepts and models in plant ecology. In connection with the increased anthropogenic load and climate change, a comprehensive study of endemic plants is becoming a necessary requirement for the conservation of biodiversity. From the representatives of a large family Lamiaceae the endemic of the Pamir-Alai Ziziphora interrupta Juz. is a widely demanded species. It is spread in the Pamir-Alai and Tien Shan mountain systems, grows on the stony-cobble and argillaceous talus mountain slopes in various types of vegetation at an altitude 700-2400 $\mathrm{m} \mathrm{[4].} \mathrm{Z.} \mathrm{interrupta} \mathrm{has} \mathrm{medicinal}$ properties due to the content of biologically active substances. It is an essential oil and melliferous plant [5, 6]. The local population uses the species as an additive to food [7]. $Z$. interrupta is harvested by local population intensively, that result in the exhaustion of its populations. To study this species, we use complex studies based on the populationontogenetic approach, which will reveal the mechanisms of adaptation and the prospects for its development in modern plant communities of Central Asia. In this regard, the aim of the work is to identify patterns of stable existence of Ziziphora interrupta coenopopulations in different ecological and geographical conditions of Tajikistan.

\footnotetext{
* Corresponding author: cher.51@mail.ru
} 


\section{Material and methods}

The structure of five coenopopulations (CP) was studied in different regions of Tajikistan. CP 1: Gissar Ridge, stony-rubble slope with a steepness of $35^{\circ}$, altitude $2100 \mathrm{~m}$; shiblyak belt with fragments of the broad-leaved forest, Amygdalus bucharica formation, total projective grass cover (TPGC) - 85\%. CP 2: Gissar Ridge, rocky-rubble slope with a steepness of $25^{\circ}-30^{\circ}$, altitude $1400 \mathrm{~m}$; shiblyak belt, Amygdalus bucharica formation, TPGC - 25\%. CP 3: Khozrati Shokh Ridge, stony rubble-clay slope with a steepness of $35^{0}$, altitude $2200 \mathrm{~m}$; a belt of thermophilic juniper forests (with fragments of the shiblyak), Juniperus seravschanica formation, TPGC - 35\%. CP 4: Pyoter Perviy Ridge, rocky-clayey talus slope with a steepness of $25-30^{\circ}$, altitude $1527 \mathrm{~m}$; the belt of thermophilic juniper forests, Juniperus seravschanica, J. semiglobosa formation, TPGC - 70\%. CP 5: Karategin Ridge, rocky-rubble slope with a steepness of $40^{\circ}$, altitude $1807 \mathrm{~m}$; a belt of large-grass semi-savannas with fragments of a shiblyak, Ferula kuhistanica formation, TPGC $-35 \%$.

The ontogenetic structure of cenopopulations was investigated according to generally accepted methods $[8,9]$. The ontogenetic spectrum was revealed when individuals were counted on 70-85 plots with a size of $1 \mathrm{~m}^{2}$. The characteristic spectrum of the CPs of the species was established according to the ideas by L.B. Zaugolnova [10]. The type of the coenopopulations was determined according to the classification by A.A. Uranova and O.V. Smirnova [11] and the classification "delta-omega" by L.A. Zhivotovsky [12]. The ecological density was established based on the number of specimens per unit of inhabited space [13].

\section{Results and discussion}

Z. interrupta is a monocentric semi-shrub [14]. Our studies have shown that the ontogeny of individuals is incomplete, there is no senile state. The duration of ontogenesis does not exceed 14-17 years. The pregenerative period is very short (1-1.5 years). Individuals enter the reproductive state in the second year after seed germination. In the generative period, the longest state is the mature generative one, it lasts up to 12 years. The polyvariance of ontogeny is described in $Z$. interrupta individuals, which is expressed in the omission of immature and subsenile states. Self-preservation of coenopopulations occurs only by seed.

The studied coenopopulations are normal, incomplete. The immature and senile groups are absent in all coenopopulations, which is associated with the peculiarities of the development of individuals in ontogenesis. In different ecological and geographical conditions the proportion of juveniles is insignificant and ranges from $0.6 \%$ to $2.5 \%$ or is absent in coenopopulations (table). The seeds of $\mathrm{Z}$. interrupta do not have a dormant period and germinate in the ripening year during the period of heavy rains in late November - early December. Seed germination is high up to $93.7 \%$, with $68 \%$ germinating after 2 days [14]. However, most of the seedlings die during an unfavorable winter period, and only a small part passes into a juvenile state.

Analysis of the individuals ordination by ontogenetic groups revealed 2 types of ontogenetic spectrum: centered and right-sided. The centered spectrum is typical for populations located in the belts of shiblyak and thermophilic juniper forests (CP 1-4). Ontogenetic spectra of CPs 1,3 are unimodal with a maximum in the mature generative group or bimodal with a local peak in virginal individuals (CPs 2 and 4). In three coenopopulations (CPs 1-3), the proportion of juveniles is very low and ranges from $0.6 \%$ to $1.5 \%$. The low percentage of the juvenile fraction is associated with their partial elimination in spring on steep stony-gravelly slopes (steepness $25-35^{\circ}$ ). Appeared amicably in autumn the seedlings die en masse, since they have a poorly developed main root, which does not allow them to gain a foothold in a mobile substrate. By-passing the immature state, 
juvenile plants in the same year pass into the virginal state, which is reflected in the increase in the virginal group in coenopopulations (from $7.7 \%$ to $14.8 \%$ ). The absence of a juvenile fraction in CP 4 and the appearance of a local peak in the virginal group in CP 2 and 4 are associated with the irregularity of seed reproduction. From the four studied coenopopulations, the largest proportion of young plants is located in the coenopopulation located in the belt of thermophilic juniper forests on the Pyoter Perviy Ridge. A low indicator was noted on the Gissar Ridge in the shiblyak belt with fragments of the broadleaved forestt. In all coenopopulations, the accumulation of mature generative individuals occurs, which is associated with an increase in the duration of this state (up to 12 years). The proportions of mature and old generative individuals differ insignificantly in three out of four coenopopulations. However, a sharp reduction in the duration of the old generative state (up to 2-3 years) and the death of most plants already in the old generative state influenced the low percentage of subsenile individuals $(0.5-2.5 \%)$ in the population. Despite the diversity of ontogenetic spectra, coenopopulations according to the «deltaomega» classification (Zhivotovsky) are characterized as mature.

Table. The ordination of the individuals by ontogenetic groups (\%) and demographic indicators of coenopopulations

\begin{tabular}{|c|c|c|c|c|c|c|c|c|c|c|c|c|}
\hline \multirow{2}{*}{$\begin{array}{c}\mathrm{C} \\
\mathrm{P}\end{array}$} & \multicolumn{7}{|c|}{ Ontogenetic groups, $\%$} & $\begin{array}{c}\text { De, } \\
\text { ind. } \\
/ \mathrm{M}^{2}\end{array}$ & $\Delta$ & $\omega$ & $\begin{array}{c}\text { Type of } \\
\mathrm{CP}\end{array}$ \\
\hline 1 & 0,6 & - & 7,7 & 12,9 & 40,0 & 37,6 & 1,2 & - & 2,9 & 0,53 & 0,84 & mature \\
\hline 2 & 1,0 & - & 14,8 & 8,8 & 47,3 & 25,6 & 2,5 & - & 3,0 & 0,49 & 0,82 & mature \\
\hline 3 & 1,5 & - & 11,8 & 11,8 & 38,0 & 36,4 & 0,5 & - & 2,5 & 0,51 & 0,81 & mature \\
\hline 4 & 0 & - & 23,9 & 8,3 & 33,3 & 33,9 & 0,6 & - & 2,8 & 0,47 & 0,77 & mature \\
\hline 5 & 2,5 & - & 15,2 & 9,3 & 32,8 & 40,2 & 0 & - & 2,8 & 0,49 & 0,75 & mature \\
\hline
\end{tabular}

Note: $\mathrm{D}_{\mathrm{e}}$ - ecological density; $\omega$ - efficiency index; $\Delta$ - age index; ontogenetic groups: $j$ - juvenale, $i m$ - immature, $v$ - virginal, $g_{1}$ - young generative, $g_{2}$ - mature generative, $g_{3}$ - old generative, $s s-$ subsenale, $s$ - senale.

The coenopopulation with a right-sided spectrum is located on the Karategin Ridge in the belt of large-grass semi-savannas (CP 5). The absolute maximum in the spectrum falls on the old generative fraction, the local maximum on the virginal one. Bimodality of the spectrum, as in other coenopopulations, is due to the irregularity of seed renewal, as well as the superposition of two waves of development. The predominance of old generative individuals is associated with the intensive harvesting of $Z$. interrupta raw materials. Cutting off aerial shoots in mature generative plants leads to their rapid aging and transition to the old generative state. The life span of the old generative plants is short, and Epy individuals completely die off without passing into the subsenial state. This coenopopulation, despite the fact that according to the classification "delta-omega" is characterized as mature, the peak in old individuals indicates its aging.

The ecological density of individuals in coenopopulations is low and ranges on average from 2.5 to 3.0 ind. $/ \mathrm{m}^{2}$. The maximum density of individuals was noted in the shiblyak belt with fragments of the broad-leaved forest at the altitude $1400 \mathrm{~m}$. In this habitat, the projective grass cover does not exceed $25 \%$, which is favorable for both the existence of virginal and generative individuals. The minimum density was noted on the Khozrati Shokh 
Ridge in the belt of thermophilic juniper forests. Under these conditions, the species is almost at the limit of altitudinal distribution, which is reflected in the density of individuals in the studied cenopopulation.

Thus, the structure of most of the studied coenopopulations of Z. interrupta under different ecological and geographical conditions does not change significantly and is determined by the biological characteristics of the species, namely, the low survival rate of seedlings, the long stay of individuals in a mature generative state, and short pregenerative and postgenerative periods in ontogenesis. The ontogenetic spectrum in such coenopopulations is centered, and the populations, based on the nature of the distribution of ontogenetic groups, are mature and normal. The deviation from the typical spectrum is mainly associated with the irregularity of seed renewal and the polyvariant ontogenesis of individuals growing on mobile substrates and steep slopes. These changes reflect spatiotemporal fluctuations occurring in coenopopulations. Z. interrupta coenopopulations with a right-sided spectrum are formed under anthropogenic stress, which affects the reduction in the duration of the stay of individuals in the mature generative state and the rapid transition to the old generative state. Coenopopulation with a right-sided spectrum will be rapidly age and drop out of the community in irregular seed renewal, mass death of seedlings and juveniles.

The work was carried out within the framework of the state assignment (No AAAAA21-121011290026-9) of the Central Siberian Botanical Garden of the SB RAS and. the projects of State Assignments ГР № 01011ТД065 and 0116ТJ00762 (Tajikistan).

\section{References}

1. O. E. Agakhanjanz, S. W. Breckle, Mountain Biodiversity: A Global Assessment (Parthenon Publ. Group, Boca Raton FL., 2002)

2. R. V. Kamelin, Florogenetic analysis of the natural flora of Middle Asia mountains (Nauka, Leningrad, 1973)

3. S. V. Yuzepchuk, Flora of the SSSR, Vol. 21 (M.-L., 1954)

4. T. F. Kochkareva, Flora of the Tajik SSR, Vol. 8 (M.-L., USSR Academy of Sciences, 1986)

5. M. B. Gholivand, M. Piryaei, S. M. Maassoumi, J. Nat. Med. 7 (2014)

6. K. Šmejkal, M. Malaník, K. Zhaparkulova, Z. Sakipova, L. Ibragimova, G. Ibadullaeva, Ž. M. Kazakh, Molecules, 21 (2016)

7. N. Z. Mamadalieva, D. Kh. Akramov, E. Ovidi, A. Tiezzi, L. Nahar, S. S. Azimova, and S. D. Sarker, Medicines, 4 (2017)

8. A. A. Uranov, Biol. Science. 2 (1975)

9. L. B. Zaugolnova, L. A. Zhukova, A. S. Komarov, O. V. Smirnov, Cenopopulations of plants (Moscow, Nauka, 1976)

10. L. B. Zaugolnova, The structure of seed plant populations and the problems of their monitoring (SPb., 1994)

11. A. A. Uranov, O. V. Smirnova, Bul. MOIP. Biol. Depart., 54 (1969)

12. L. A. Zhivotovsky, Rus. Ecol. (2001)

13. Yu. Odum, Fundamentals of Ecology. (Moscow, Mir, 1975)

14. K. A. Bobokalonov, V. A. Cheryomushkina, M. T. Boboev, BIO Web of Conferences 24 (2020)

15. K. Bobokalonov, V. Cheryomushkina, BIO Web of Conferences 11 (2018) 